Aneta Firlej-Buzon

Uniwersytet Wrocławski, Wrocław, Polska

aneta.firlej-buzon@uwr.edu.pl

\title{
„Dar książki dla Wrocławia i Śląska” - powojenne akcje społeczne na rzecz polskich bibliotek w Okręgu II Dolny Śląsk z lat 1945-1948 w świetle wybranych źródeł
}

\author{
"A gift of a book for Wrocław and Silesia" - post-war social \\ campaigns for Polish libraries in District II Lower Silesia from \\ 1945-1948 on the base of choosen resources
}

\begin{abstract}
Poles displaced to the so-called Recovered Territories, organizing here the social life, struggled with the lack of Polish books. An acute shortage was felt by the entire community, especially by children, pupils and students from Wrocław universities rebuild from the ruins. In order to satisfy the hunger for the Polish word and Polish books, there were organized numerous of social campaigns, both nationwide, regional and local. The authors of this campaigns were the central authorities and representatives of the Lower Silesian administration, as well as associations established in the District II, and finally private persons acting in the field of education, culture or entertainment. Books obtained thanks to social campaigns were the beginning of libraries book collections.
\end{abstract}

Key words: Lower Silesia, social campaigns and donations for the purchase of books Słowa kluczowe: Dolny Śląsk, społeczne zbiórki książek i datków na zakup książek, 1945-1948 
Pani Profesor Barbara Bieńkowska

Wielce Szanowna Pani Profesor,

Z okazji pięknego jubileuszu, w imieniu catej akademickiej społeczności

Instytutu Informacji Naukowej i Bibliotekoznawstwa Uniwersytetu Wrocławskiego, proszę o przyjęcie najserdeczniejszych gratulacji, wyrazów uznania dla dorobku naukowego Pani Profesor i podziękowań za wkład w rozwój nauki polskiej.

Pragnę też życzyć Pani Profesor wszelkiej pomyślności, dużo radości oraz wielu lat zdrowia!

Z wyrazami szacunku dr hab. Aneta Firlej-Buzon, prof. UWr

\section{RODACY!}

Po 600 latach ponownie na prastarej ziemi Chrobrego rozbrzmiewa język Mickiewicza, Sienkiewicza i Słowackiego. Potęga naszych wojsk i broni wyparła krzyżackiego zaborcę, wniosła w krainę Odry i Nysy wolność Polskiej (sic!) mowy! Czyn zbrojny, wyrównanie odwiecznej niesprawiedliwości musi być utrwalony, musi istnieć wiecznie! (..)

RODACY!

Ojczyzna nas wzywa w imię wspólnego dobra! Przyjdźcie z pomocą mowie Polskiej (sic!) na ziemi Bolesławów! DAR KSIAŻKI DLA WROCŁAWIA I ŚLĄSKA - TO OBOWIĄZEK! SPEŁNIJCIE GO WZOREM ŻOŁNIERZA POLSKIEGO! ${ }^{1}$

\section{Wstęp}

Polacy przymusowo przesiedleni z tzw. Kresów Wschodnich lub przybywający ze zburzonej Warszawy na Ziemie Zachodnie i Północne organizowali tu od podstaw życie społeczne. Wśród licznych, bardzo poważnych problemów wynikających z migracji i wymiany ludności, poważną przeszkodą w procesie kształtowania polskiej kultury na Ziemiach Odzyskanych był brak polskich książek i polskiego słowa. Problem ten dostrzegały władze krajowe oraz regionalne i lokalne mianowane mocą Dekretu PKWN z dnia 21 sierpnia 1944 roku o trybie powołania władz administracji ogólnej I-ej i II-ej instancji (Dz. U. 1944 nr 2 poz. 8). W sierpniu 1945 r. Ministerstwo Oświaty przysłało na Dolny Śląsk 50 kompletów książek, gównie lektur szkolnych, m.in. „Krzyżaków”, „Noc listopadową"”. Te skromne zasoby, przekazane z myślą

1 Afisz z października 1945 r. „Dar książki dla Wrocławia i Śląska” wydany przez „Pionier” Zakłady Graficzne we Wrocławiu, zachowany w zbiorach Biblioteki Uniwersyteckiej we Wrocławiu.

2 „Pionier. Dziennik Dolno-Śląski”, 31 VIII 1945, nr 5, s. 4. 
o zaczątku bibliotek powiatowych, zostały rozdzielone pomiędzy 36 inspektoratów szkolnych na terenie całego Okręgu II. Kilka kompletów trafiło w posiadanie urzędników z Wojewódzkiego Wydziału Kultury i Sztuki. Sprawa polskich książek była też przedmiotem troski organizacji, stowarzyszeń oraz związków, głównie o charakterze edukacyjnym, naukowym lub pomocowym. Działalność tych podmiotów służyła podnoszeniu poziomu oświaty społeczeństwa bądź dobru publicznemu.

Głód polskiego słowa, lektur szkolnych, podręczników, książek akademickich i naukowych starały się zaspokajać m.in. kuratoria okręgów szkolnych, związki zawodowe, stowarzyszenia młodzieży oraz Biblioteka Jagiellońska. Ci rzecznicy polskiej książki na Dolnym Śląsku już w październiku 1945 r. ogłosili akcję „Dar książki dla Wrocławia i Śląska”. W latach 1945-1947, w pionierskim okresie zasiedlania Dolnego Śląska sprawą książki polskiej zajmowały się również organizacje i instytucje konstytuujące się już w Okręgu II, m.in. urzędy i szkoły podstawowe oraz średnie. Do tego rodzaju podmiotów zaliczały się również stowarzyszenia otaczające szczególną troską liczne ofiary wojny, sieroty, wdowy, osoby okaleczone, byłych więźniów hitlerowskich obozów koncentracyjnych oraz innych znajdujących się w bardzo trudnej sytuacji materialnej np. pochodzących z Kresów i pozostających bez dachu nad głową demobilizowanych żołnierzy. Rzecznikami polskich książek byli na Dolnym Śląsku również sami przesiedleni, nieliczni znani z imienia i nazwiska, którzy nie szczędzili pracy, ani skromnych zasobów finansowych, by wspomagać organizujące się biblioteki własnymi książkami lub datkami pieniężnymi.

Informacje o zbiórkach książek dla urządzanych od podstaw bibliotek ogłaszano w treści wielkoformatowych druków ulotnych. Wydawnictwa te jednocześnie stanowiły wyraz troski o słowo polskie, o obecność języka polskiego w przestrzeni medialnej Okręgu II Dolny Śląsk. Warto dodać, iż dokumenty ulotne i okolicznościowe, afisze, plakaty, apele, wezwania, ogłoszenia i hasła propagandowe $\mathrm{w}$ okresie przymusowych, pospiesznych migracji i powojennego chaosu, stanowiły na Ziemiach Odzyskanych jedyne nośniki języka polskiego. Celem niniejszego tekstu będzie przedstawienie faktów nt. akcji zbiórek książek dla dolnośląskich bibliotek lub kwest środków finansowych na zakup księgozbiorów a także ujawnienie zachowanych danych nt. najwcześniej funkcjonujących w Okręgu II Dolny Śląsk bibliotek lub wypożyczalni. Podstawą opisanych w niniejszym artykule faktów będą pochodzące głównie ze zbiorów Gabinetu Śląsko-Łużyckiego Biblioteki Uniwersyteckiej we Wrocławiu źródła ulotne - głównie apele, wezwania, afisze, odezwy oraz hasła propagandowe edytowane najczęściej w podnoszonych z gruzów drukarniach uruchamianych w regionie. Do opracowania niniejszego tekstu przejrzano ponad 1000 tego rodzaju druków dotychczas nieopracowanych oraz nieposiadających sygnatur. Wśród tego zasobu oryginalnych publikacji, odnaleziono kilkanaście druków 
zapowiadających zbiórki książek lub datków na potrzeby ich zakupu. Źródła do niniejszego tekstu stanowić będą również inne dokumenty - wspomnienia dolnośląskich pionierów a także informacje podawane w „Pionierze. Dzienniku Dolno-Śląskim”. Periodyk ten publikowany w Okręgu II Dolny Śląsk już od sierpnia 1945 r. dla społeczności przybywającej do regionu był początkowo jedynym czasopismem dostępnym osiedlającym się. Wśród podawanych tu danych odnaleziono notki i doniesienia o zbiórkach książek dla bibliotek, akcjach takich jak „,ańcuchy ofiar”, a także informacje o otwieranych bibliotekach, ich adresach oraz godzinach pracy. Fakty te oprócz danych faktograficznych ujawniają, jak ważnymi instytucjami dla przesiedlonych były biblioteki. W tekście zaprezentowani zostaną także organizatorzy kwest oraz charakter przygotowanych przez nich akcji służących zaopatrywaniu przesiedlonej ludności w książki. Niektóre z nich były przedsięwzięciami autonomicznymi lub wydarzeniami towarzyszącymi różnego rodzaju obchodom albo świętom ważnym dla lokalnej społeczności. Zbiórki książek stanowiły też znamiennie często element programu imprez rozrywkowych lub sportowych, bardzo chętnie urządzanych w pierwszych powojennych latach, zwłaszcza w okresie 1946-1948. Kolekty na rzecz bibliotek towarzyszące zabawom tanecznym, józefinkom, andrzejkom, meczom piłkarskim, były z pewnością okazją do nawiązania kontaktów, jednoczenia się i budowania relacji społecznych. Stanowiły jednocześnie wyraz troski o zapewnienie członkom lokalnych wspólnot, szczególnie dzieciom i młodzieży, kontaktu z językiem ojczystym i polską kulturą.

Sprawa dostępu do polskich książek, elementarzy, lektur i podręczników szkolnych była bardzo ważna dla co najmniej kilku roczników dzieci, które wskutek wojny i okupacji utraciły szansę na tradycyjną edukację szkolną oraz rozwinięcie zdolności i zainteresowań. Dzieciom tym starano się w miarę skromnych możliwości warunkowanych m.in. zniszczeniami wojennymi, chaosem przesiedleń, brakiem kadry nauczycielskiej, zrekompensować utracone lata uruchamiając stopniowo placówki oświatowe np. do pierwszego przedszkola otwartego we wrocławskiej dzielnicy Karłowice w sierpniu 1945 r. rekrutowano dzieci w wieku od 3 do 7 lat włącznie. Zgodnie z zarządzeniem Ministra Oświaty z dnia 11 V 1946 r. Nr 2/2200/46 w roku szkolnym 1946/1947 obowiązkowi szkolnemu podlegały dzieci urodzone w latach 1933-1939. Dzieciom urodzonym w roku 1932, które ukończyły z wynikiem pozytywnym co najmniej 5. klasę szkoły powszechnej, przedłużono o rok obowiązek szkolny. We wrześniu 1945 r. Kuratorium Okręgu Szkolnego Wrocławskiego we Wrocławiu organizowało w stolicy Dolnego Śląska oraz w Jeleniej Górze m.in. kursy wstępne pedagogiczne dla absolwentów liceów, kursy kwartalne dla absolwentów gimnazjów dające możliwość dalszego kształcenia w liceum pedagogicznym oraz skrócony do lat dwóch kurs gimnazjalny dla liczących od 
16 do 20 lat absolwentów sześcioklasowej szkoły powszechnej ${ }^{3}$. Problem braku podręczników akademickich i periodyków naukowych dotykał równie silnie młodzież akademicką pragnącą nadrobić stracony czas oraz zdobyć wyższe wykształcenie w uczelniach, które władze powojennej Polski powołały mocą Dekretu z dnia 24 sierpnia 1945 r. o przeksztatceniu Uniwersytetu Wroctawskiego i Politechniki Wroctawskiej na polskie państwowe szkoły akademickie (Dz. U. 1945 nr 34 poz. 207). Odrębną kwestię warunkowaną powszechną obecnością polskiego języka, literatury, prasy, jak również radia i telewizji na Dolnym Śląsku, stanowiły próby szybkiego scalenia Ziem Odzyskanych $\mathrm{z}$ resztą kraju. Bez słowa polskiego i pisanych w ojczystym języku publikacji zadanie to nie było możliwe do realizacji.

Dzięki wysiłkowi organizatorów akcji zbiórek książek, jak i darczyńców nie szczędzących środków finansowych na wspieranie bibliotek, dostęp do literatury narodowej stopniowo stawał się na Dolnym Śląsku powszechny i tani. W bardzo trudnej sytuacji przesiedlonych, którzy w pierwszych powojennych latach borykali się z różnymi poważnymi problemami i niedostatkami, miało znaczenie nadrzędne. Wbrew propagandzie długo upowszechnianej przez rząd komunistyczny repatriowani Polacy przybyli do zbiedniałego regionu, który podupadał już w czasie II wojny światowej, a po jej zakończeniu stał się wyłącznym łupem wojennym ZSRR. Oznaczało to długoletnią eksploatację ziemi przyznanej Polakom, którzy jednak nie mogli nią w pełni zarządzać. Wyzysk nakazany rozkazami Stalina ws. zdobyczy wojennych i reparacji rozpoczął się wraz z wkroczeniem do regionu Armii Czerwonej i tzw. „trofiejnych otriadów” specjalizujących się w poszukiwaniu cennych dóbr, w tym książek. Niekontrolowana przez władze polskie eksploatacja trwała aż do grudnia roku 1956. Wówczas dopiero sprawy obecności wojska radzieckiego na terytorium Polski udało się w pewnym zakresie uregulować prawnie ${ }^{4}$.

\section{Sytuacja przesiedlonych do Okręgu II Dolny Śląsk}

Ciężkie doświadczenia wojny i kolejnych okupacji, a następnie ekspatriacja, zwana przez bezpośrednich świadków przesiedleń z roku 1945 deportacją z byłych województw II Rzeczypospolitej, stały się dla Polaków migrujących na Ziemie Odzyskane doświadczeniem niezwykle trudnym. Polacy zamieszkujący tereny, które mocą dekretu z dnia 2 XI 1939 r. Rady Najwyższej ZSRR

3 Ogłoszenie Kuratorium Okręgu Szkolnego Wrocławskiego we Wrocławiu z dnia 15 IX 1945 r., wydane przez „Pionier” Zakłady Graficzne we Wrocławiu, zachowany w zbiorach Biblioteki Uniwersyteckiej we Wrocławiu.

4 Aktem prawnym była Umowa między Rządem Polskiej Rzeczypospolitej Ludowej a Rządem Związku Socjalistycznych Republik Radzieckich o statusie prawnym wojsk radzieckich czasowo stacjonowanych w Polsce, podpisana w Warszawie dnia 17 XII 1956 r., Dz. U.1957.29.127. 
oraz uchwał Rad Najwyższych Republik Ukraińskiej i Białoruskiej o przyjęciu zachodnich obwodów w skład terytoriów republik ZSRR, traktowani byli jako tzw. „element antyradziecki”s. Ludność przybyła do Okręgu II Dolny Śląsk przeżyła w latach 1939-1945 skrajnie trudne doświadczenia i represje, w tym deportacje, które na ziemiach polskich anektowanych przez Związek Radziecki rozpoczęły się już w październiku 1939 r., aresztowania, przymusowe wcielania do batalionów budowlanych tzw. strojbatów stanowiących formację pomocniczą Armii Czerwonej, jak i przymusowe pobory do Armii Czerwonej Polaków, tzw. nowobrańców z roczników 1917-1920 i in. ${ }^{6} \mathrm{~W}$ latach 1940-1941 miały miejsce cztery masowe deportacje ludności polskiej, które objęły również uciekinierów z niemieckiej strefy okupacyjnej. Liczba ofiar sowieckiego terroru ukierunkowanego na wyniszczenie ludności polskiej była ogromna. W świetle badań Andrzeja Paczkowskiego opublikowanych w Czarnej księdze komunizmu. Zbrodnie, terror, prześladowania ponad milion obywateli polskich było bezpośrednimi ofiarami represji, czyli dotknęły one co dziesiątego Polaka. Statystyka ta nie oznacza, iż pozostali członkowie polskiej społeczności nie doświadczyli prześladowania, strachu, bezprawia, rabunku i zaboru mienia, dyskryminacji, eksploatacji jako tania siła robocza lub innych rodzajów krzywdy. Sytuację ludności polskiej w anektowanym przez ZSRR Lwowie, w czasie pierwszej z masowych deportacji ze stycznia 1940 r. opisała w swoich Wspomnieniach wojennych Karolina Lanckorońska:

Na drugi dzień, 12 lutego [1940 r.], popłoch padł na Lwów. Na wszystkich dworcach zjawiały się coraz to nowe pociągi, długie rzędy wagonów bydlęcych stawały na torach. Rozlegały się śpiewy. Najczęściej śpiewano Gorzkie żale, gdyż był to przecież Wielki Post. Pociągów pilnowało wojsko. Ludność miejska i podmiejska spontanicznie rzuciła się na dworce. Jeśli wagonów pilnował Kirgiz czy Kałmuk, to rady nie było; jeśli tam stał Moskal, udawał nieraz, że nic nie widzi, czasem nawet podawał sam wodę czy strawę, mleko czy lekarstwa przez malutkie zakratowane górne okienko. Zimno było straszliwie. Tak rozpaczliwe były wówczas te nieprzerwane mrozy, jak rozpaczliwa była we wrześniu nieprzerwana pogoda. Pociągów na dworcach ciągle przybywało. Wagony były zamknięte, zezwalano tylko i to nie zawsze - na wyrzucanie zwłok. Zbierano je wieczorem na torach. Dużo było wśród nich zamarzniętych dzieci. Pokazało się, że nie wszędzie można było zabierać pierzyny jak w Klicku, z niektórych wsi kazano ludziom wyjść bez niczego, jeśli tego żądał miejscowy ukraiński sowiet.

Pociągi przybywały z okolic na zachód i na północ od Lwowa, a wiadomości przychodziły zewsząd, ze wszystkich województw i powiatów zaboru. Zewsząd wywożono Polaków

5 Na mocy Dekretu Prezydium Rady Najwyższej ZSRR z dnia 29 XI 1939 r. wszystkim osobom, które w dniach 1 i 2 XI 1938 r. przebywały na terytorium RP zajętym przez Armię Radziecką po dniu 17 IX 1939 r. nadane zostało obywatelstwo ZSRR bez względu na ich narodowość oraz poprzednie obywatelstwo, Uchwała Sądu Najwyższego z dnia 22 marca 1989 r. III UZP 9/89.

6 M. Wieliczko, Raport o ,strojbatach”, „Annales Univesitatis Mariae Curie-Skłodowska Lublin Polonia" 2008, nr 58, s. 119. 
pochodzących z sąsiednich wsi, którzy nabyli ziemię po roku 1918, jako element „napływowy”, „sztucznie” tam przez Rząd Polski usadowiony. Poza tym zabierano wówczas tylko zawodowych leśników. Na torach za dworcami lwowskimi stał cały park wagonów bydlęcych, przeciętnie po 80 osób w wagonie, Jedni umierali, drudzy się rodzili - a mróz trzymał. Wreszcie pierwsze pociągi ruszyły na wschód. Zawsze, bez wyjątku, w tej chwili najstraszniejszej godzinie rozbrzmiewał śpiew zawsze ten sam, a raczej zawsze te same dwie pieśni: Rota lub Boże, coś Polskę...7

Od 1943 r. Polacy zamieszkujący województwo wołyńskie, tarnopolskie, stanisławowskie i lwowskie padali ofiarą brutalnych czystek etnicznych, ludobójstwa. Liczbę pomordowanych w rzezi wołyńskiej szacuje się obecnie na 40-70 tys. Analogicznie tragiczna sytuacja panowała również w Małopolsce Wschodniej. W panicznych ucieczkach przed eksterminacją wiosną i latem 1944 r. opuściło swoje domy od 300 do 400 tys. obywateli polskich, z samego Lwowa zaś uciekło ok. 40-45 tys. mieszkańców. Ludzie uciekali także w obawie przed wyzwoleniem przez Armię Czerwoną.

W świetle szacunków Andrzeja Gawryszewskiego opisanych w pracy Ludność Polski w XX wieku, w latach 1944-1948 do Polski repatriowano 1189,3 tys. osób ${ }^{8}$. Z tej liczby do Okręgu II Dolny Śląsk, a następnie do województwa wrocławskiego w granicach terytorialnych według podziału administracyjnego z 28 VI 1946 r., przybyło łącznie 410377 osób, w tym z Litewskiej SRR 18050 osób, Ukraińskiej SRR 114679 osób oraz z Białoruskiej SRR 216483 osoby. Wśród społeczności przesiedlanych 33,3\%, czyli ok. 140 tys. osiedlających się, stanowili chłopi, pracownicy umysłowi $(23,1 \%)$, robotnicy $(16,6 \%)$ i rzemieślnicy $(11,6 \%)^{9}$. Liczną grupą osiedlających się na Dolnym Śląsku były także ofiary ostatniej masowej niemieckiej akcji wysiedleńczej z października roku 1944, kiedy po klęsce powstania warszawskiego Niemcy wypędzili ok. 550 tys. mieszkańców zrównanej z ziemią stolicy $^{10}$. Według szacunków Krzysztofa Dunin-Wąsowicza ok. 150 tys. wypędzonych warszawiaków trafiło na roboty do Rzeszy, w tym m.in. w okolice Wrocławia ${ }^{11}$. Ok. 60 tys. osób, podejrzewanych o czynny udział w powstaniu było więzionych w hitlerowskich obozach śmierci m.in. w KL Auschwitz, KL Dachau, KL Ravensbruck, KL Mauthausen-Gusen, KL Buchenwald. Trzy tysiące mężczyzn trafiło do KL Gross-Rosen na Dolnym Śląsku ${ }^{12}$. Jak pisze A. Gawryszewski część z wypędzonych i więzionych warszawiaków wracała

7 K. Lanckorońska, Wspomnienia wojenne, Kraków 2001, s. 23.

8 Jak podaje A. Gawryszewski w latach 1944-1949 powróciło do Polski ze Wschodu 1525 tys. osób. A. Gawryszewski, Ludność Polski w XX wieku, Warszawa 2005, s. 443.

9 Tamże.

10 Tamże, s. 488-489.

11 K. Dunin-Wąsowicz, Warszawa w latach 1939-1945, Warszawa 1984, s. 355.

12 Tamże. 
w 1945 r. do Polski z Zachodu m.in. z żołnierzami pierwszej dywizji pancernej gen. Stanisława Maczka oraz z polskimi jeńcami wojennymi ${ }^{13}$.

Represje, deportacje i czystki etniczne, których celem było wyniszczenie Polaków, jak i ciężkie warunki okupacyjnej egzystencji sprawiły, że zaburzona została struktura wieku i płci repatriowanych, którzy bezpośrednio po wojnie przybyli do Okręgu II Dolny Śląsk. W świetle ustaleń A. Gawryszewskiego na 126 kobiet przypadało zaledwie 100 mężczyzn, odsetek osób poniżej 18. i powyżej 60. roku znacznie odbiegał od proporcji wykazywanych na obszarach Polski, których ludność nie została doświadczona przymusowymi wysiedleniami ${ }^{14}$. Statystyki wskazywały, iż wojny i okupacji nie przetrwali najsłabsi - najmłodsi oraz najstarsi. Zachwianie proporcji demograficznych, przerwanie naturalnego porządku pokoleniowego oraz skrajna pauperyzacja a także inne czynniki, stanowiły obciążenie dla przymusowo przesiedlonych. Jak pisał J. Wałęga w wydanej w Rzymie w 1945 r. publikacji Deportacje i przesiedlenia „stan psychiczny przesiedleńców jest »rzadko spotykaną depresją«, a fizyczny jest taki, że co najmniej 50 do $60 \%$ z pośród nich będzie bez najmniejszego pożytku da Polski”"15. Ci, którym udało się przetrwać wojnę i odczekać przesiedlenia, przybyli na ziemię krzywdzicieli skrajne spauperyzowani. Przymusowo migrujący do Okręgu II Dolny Śląsk teoretycznie mieli możliwość sprzedaży swojego majątku nieruchomego, który każdorazowo był wyceniany przez delegata właściwego komisariatu ludowego Ukraińskiej SRR, Białoruskiej SRR i Litewskiej SRR. Należność za nieruchomości nie była jednak przekazywana właścicielom. Jej równowartość miała być przekazana Skarbowi Polskiemu, a rozliczenie otrzymanej kwoty odłożono na przyszłość. Były właściciel dostawał ekwiwalent $500 \mathrm{zł}$ w rublach, które na granicy musiał zamienić na tzw. bierutki - wewnętrzną, całkowicie niewymienialną walutę drukowaną w ZSRR dla krajów satelickich. Co ciekawe, kurs bierutek różnił się w zależności od punktu odbiorczego Państwowego Urzędu Repatriacyjnego (PUR) odpowiedzialnego za „organizację repatriacji ludności z obszarów innych państw niż terytorium Państwa Polskiego" oraz organizację osadnictwa repatriowanych ${ }^{16}$. Punkty, w których urzędowali polscy pełnomocnicy znajdowały się w Wilnie dla osób przesiedlanych z Litewskiej SRR, Baranowiczach dla opuszczających Białoruską SRR i w Łucku dla wyjeżdżających z Ukraińskiej SRR. W niektórych tzw. punktach wlotowych w latach 1945-1947 przewinęło się po pół milion osób. Przesiedleńcy mieli teoretycznie możliwość zabierania ze sobą

\footnotetext{
13 A. Gawryszewski, dz. cyt., s. 450.

14 Tamże, s. 443-444.

15 J. Wałęga, Deportacje i przesiedlenia, Rzym 1945, s. 7.

16 Obwieszczenie Ministra Administracji Publicznej z dnia 17 lipca 1945 r.w sprawie ogłoszenia jednolitego dekretu PKWN z dnia 7 października 1944 r. o utworzeniu Państwowego Urzędu Repatriacyjnego, Dz. U. 1945 nr 24 poz. 145.
} 
majątku ruchomego - mebli, zboża, narzędzi rolniczych oraz inwentarza żywego. Problemem był jednak transport tego mienia na dworce kolejowe. Również po drugiej stronie granicy sytuacja nie sprzyjała przewozowi dobytku - PKP, które przygotowało pociągi dla repatriantów nie dysponowało wystarczającą liczbą wagonów. Do tego radzieccy weterynarze znamiennie często stwierdzali groźne choroby bydła, które po diagnozie musiały zostać w ZSRR ze względu na zagrożenie epidemiologiczne. W praktyce więc wysiedlani Polacy zabierali tylko to, co mogli udźwignąć. $Z$ uwagi na brak informacji, o miejscach docelowych i warunkach tam panujących oraz w obawie przed groźbą głodu, ludzie zabierali ze sobą przede wszystkim zapasy zboża. Jak w swoim opracowaniu pisał J. Wąłęga ,dobytek przesiedlonych ginie po drodze, mało kto ma bodaj jedną zmianę bielizny"17. Trudno dzisiaj znaleźć odpowiedź na pytanie, ilu z przesiedlonych zdołało przywieźć do Polski swoje książki? W świetle wspomnień K. Lanckorońskiej już na przełomie 1939/1940 r. „w antykwariatach było coraz ciaśniej, rzeczy coraz ładniejsze tam wypływały - to Lwów wyprzedawał swoją tradycję i swoją kulturę, żeby żyć"18.

Opisane obciążenia poważnie wpłynęły na proces odradzania się relacji społecznych w środowisku przesiedlonych po II wojnie światowej, ograniczały warunki rozwoju kolejnych generacji i przygotowania ich m.in. do obowiązków rodzinnych, zawodowych oraz społecznych i obywatelskich. Ogromny problem dotyczył edukacji dzieci i młodzieży. Na ziemiach polskich anektowanych przez ZSRR szkolnictwo polskie zostało zunifikowane z sowieckim systemem oświaty w celu szerzenia ideologii komunistycznej, uczniowie uczyli się z podręczników będących przekładami podręczników radzieckich - ,polski został zredukowany do czytania i pisania, nauka religii skasowana. Na jej miejscu urządzano pogadanki o raju sowieckim, o dobroci batki Stalina, najlepszego opiekuna, o okrucieństwach panów polskich i o prześladowaniu robotnika" 19 . W szkołach wielonarodowych językiem wykładowym był rosyjski. Zlikwidowano Uniwersytet Stefana Batorego w Wilnie, uczelnie lwowskie działały, choć językiem wykładowym był ukraiński, systematycznie wymieniano w nich kadrę a polskich studentów wcielano do Armii Czerwonej. Po 22 VI $1941 \mathrm{r}$. nowy okupant rozpoczął politykę planowej eksterminacji, wynaradawiania bądź germanizowania praktykowaną od 1939 r. na ziemiach polskich, które weszły w skład terytorium Rzeszy oraz w Generalnym Gubernatorstwie. Niemcy nie zezwolili na istnienie polskich szkół i kontynuowali likwidację polskiej inteligencji wraz z rodzinami. Na terenie Galicji funkcjonowały natomiast szkoły zawodowe, we Lwowie zaś dla młodzieży ukraińskiej zorganizowano kursy

17 J. Wałęga, dz. cyt., s. 7.

18 K. Lanckorońska, dz. cyt., s. 15.

19 Tamże, s. 20-21. 
zawodowe, do udziału w nich dopuszczano Polaków. Na ziemiach polskich anektowanych przez Związek Radziecki z różnych przyczyn nie rozwinęło się tajne nauczanie, choć jak wspominała Karolina Lanckorońska „Jeśli chodzi o historię i literaturę polską oraz o naukę religii, to dzieci w latach wojennych kształcone niewątpliwie o tych rzeczach wiedziały znacznie więcej niż ich poprzednicy. Uczono się $\mathrm{w}$ domu przedmiotów zakazanych $\mathrm{z}$ namiętnością dawniej nie widzianą, Polska i religia zlały się w młodzieńczych umysłach $\mathrm{w}$ jedną nierozerwalną całość, zgodnie z tradycją, a wylana za te ideały ofiara krwi młodzieży szkolnej była również zgodna z tradycją..."20.

Przybyli do Okręgu II Dolny Śląsk musieli mierzyć się nie tylko z organizowaniem od podstaw szkolnictwa różnego szczebla, ale również podejmowali próby nadrobienia straconego czasu i uzupełniania braków edukacyjnych. Świadczy o tym choćby treść pochodzącego z 20 VII 1945 r. wezwania Inspektora Szkolnego we Wrocławiu Władysława Tkaczyka adresowanego do mieszkańców Wrocławia. Druk informował o zapisach dzieci do szkół w dniach 20 VII - 1 VIII 1945 r.:

Będzie to bardzo ważna data, szczególnie na terenie Dolnego Śląska, a więc i Wrocławia, gdy otwarte zostaną pierwsze od wieków szkoły polskie. O ilości i rodzaju tych szkół zadecyduje liczba dzieci i młodzieży.

Ogłasza się przeto zapisy do szkół powszechnych oraz średnich ogólnokształcących i zawodowych (gimnazjum, liceum). Zapisy te stanowić będą ważny materiał dla Władz Szkolnych przy zorganizowaniu tutejszego szkolnictwa.

Zapisywać należy dzieci i młodzież, która znajduje się już na terenie miasta Wrocławia oraz tych, którzy przybędą tutaj do dnia 1 września 1945 r.

Polacy, dopilnujcie tej ważne sprawy!

Niech na odzyskanym terenie prastarej naszej ziemi nie znajdzie się ani jedno dziecko polskie poza szkołą.

Niech tutejsze społeczeństwo polskie otoczy serdeczną opieką szkołę, ten ważny czynnik naszego bytu narodowego i państwowego!21.

Pierwszy rok szkolny i pierwszy rok akademicki w Okręgu II Dolny Śląsk były dla przesiedlonych szczególnie ważne. Organizowano liczne zbiórki wszelkiego rodzaju pomocy szkolnych, mebli, sprzętu sportowego oraz odzieży sportowej, rzeczy zimowych i butów dla dzieci. Studenci, którzy chcieli nadrobić sześcioletnie zaległości, intensywnie poszukiwali podręczników akademickich. W tzw. sortowniach książek próbowano znaleźć publikacje i podręczniki, które mogły być podstawą warsztatu pracy naukowej, jakim wkrótce stać się miała Biblioteka Uniwersytecka we Wrocławiu. Książek, które „wydobywano

20 Tamże.

21 Wezwanie Do rodziców i opiekunów dzieci i młodzieży Inspektora Szkolnego we Wrocławiu z 20 VII 1945 r., ze zbiorów Biblioteki Uniwersyteckiej we Wrocławiu. 
nieraz dosłownie spod ziemi" poszukiwano wszędzie - w piwnicach, na strychach, w gruzach i na śmietnikach ${ }^{22}$. Pomimo faktu, iż każdy tom, który nadawał się do włączenia do księgozbioru, stanowił cenne znalezisko, książek polskich na Dolnym Śląsku dramatycznie brakowało. Niejednokrotnie zdarzało się, iż odnajdywano ukradzione przez Niemców polskie księgozbiory ukryte na Ziemiach Odzyskanych, w tym na Dolnym Śląsku uchodzącym długo za bezpieczny region Rzeszy. Niemcy przechowywali tu zarówno własne zasoby kultury np. w Jeleniej Górze zdeponowane zostały np. instrumenty zespołu Państwowej Opery Berlińskiej, jak i zagrabione mienie z okupowanej Polski, m.in. w Przesiece znaleziono obrazy Jana Matejki zrabowane z Narodowej Galerii Sztuki Zachęta, w Cieplicach zaś obrazy ukradzione z Muzeum Narodowego w Warszawie i Krakowie, Wilanowa i Łazienek ${ }^{23}$. W roku 1945, w Lubawie. W obecnym województwie warmińsko-mazurskim, kierownik szkoły odnalazł 634 egzemplarze książek medycznych ukradzionych przez Niemców i stanowiących część zbiorów bibliotecznych Uniwersytetu Warszawskiego im. Józefa Piłsudskiego ${ }^{24}$. Z kolei w sierpniu 1945 r. na stacji kolejowej w Bystrzycy żołnierze Armii Czerwonej odnaleźli 26 wagonów książek pochodzących z bibliotek europejskich, w tym wywiezionych z Polski m.in. z Biblioteki Francuskiej w Warszawie oraz Biblioteki Seminarium Duchownego w Pelplinie ${ }^{25}$. Antoni Knot - organizator Biblioteki Uniwersytetu Wrocławskiego, od 9 V 1945 r. obecny we Wrocławiu, jeden z nielicznych wówczas w Okręgu II Dolny Śląsk znawców bibliotekarstwa oraz archiwistyki, do końca 1946 r. przeszukał wraz z grupą osób ratujących ukryte zasoby biblioteczne „ponad 70 schowków (groty wykute w skałach, zamki, pałace itp.) i odzyskali tysiące cennych rękopisów, starych druków, muzykaliów, zbiorów graficznych, archiwaliów, zbiorów mineralogicznych, zielniki - kilkanaście tysięcy tek, z których część wróciła do Biblioteki Uniwersyteckiej”26.

22 Odezwa Konkurs na pamiętnik Studenta Wrocławskiego, Polski Instytut Socjologiczny, Łódź, maj 1949 r., ze zbiorów Biblioteki Uniwersyteckiej we Wrocławiu.

23 E. Basałygo, 900 lat Jeleniej Góry, Jelenia Góra 2010, s. 185-186.

24 Fragment wspomnień historyka i pracownika Wydziału Kultury Urzędu Miejskiego we Wrocławiu Bogumiła Miłaszewskiego, s. 6, mps ze zbiorów BZNiO.

25 „Pionier. Dziennik Dolno-Śląski”, 29 VIII 1945, nr 3, s. 4.

26 Książki i inne zasoby biblioteczne odzyskane przez grupę poszukiwawczą kierowaną przez A. Knota trafiły m.in. do Biblioteki Narodowej, Jagiellońskiej, uniwersyteckich w Warszawie i Lublinie oraz innych bibliotek naukowych w kraju [za:] J. Szocki: Antoni Knot (1904-1982), „Nauka Polska" 1982, nr 1-2, s. 269-271; wkład A. Knota w organizację oraz rozwój bibliotekarstwa naukowego na Dolnym Śląsku omówiony został m.in. w artykule A. Firlej-Buzon pt. Działalność prof. Antoniego Knota w organizacji bibliotekarstwa naukowego na Dolnym Ślasku w latach 1945-1956, „Zielonogórskie Studia Bibliotekoznawcze” 2017, z. 9, s. 155-166. 
I1. 1. Pełnomocnictwo dla Antoniego Knota kierownika Referatu Rewindykacyjnego

Uniwersytetu i Politechniki we Wrocławiu uprawniające do rewindykacji wywiezionego przez Niemców mienia Uniwersytetu i Politechniki Wrocławskiej oraz przejmowania na rzecz Uniwersytetu wszelkich bibliotek poniemieckich na terenie Dolnego Śląska. Źródło: Dział Dokumentów Życia Społecznego BZNiO, zasób „Antoni Knot”

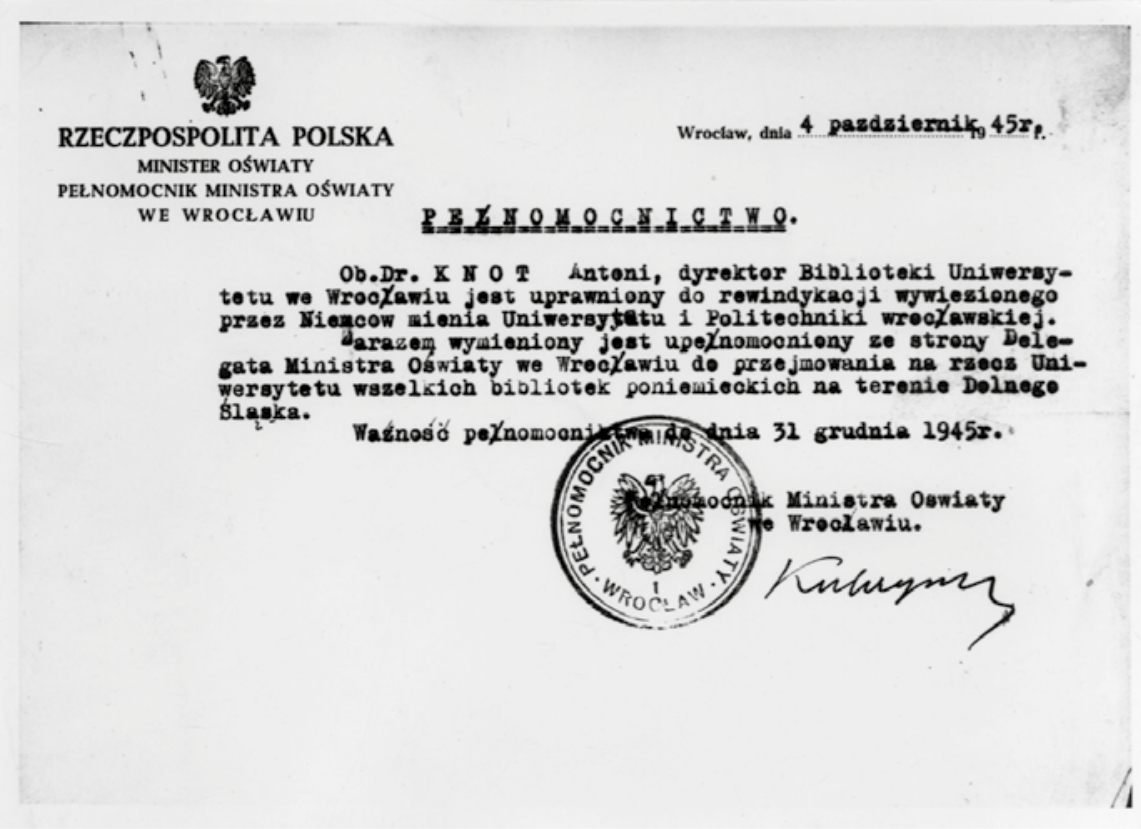

Starania o odzyskanie polskich publikacji podjęło m.in. Ministerstwo Kultury i Sztuki u przedstawicieli ZSRR. Natomiast we wrześniu 1945 r. w miejscowości Kwiatowo niedaleko Dzierżoniowa odnaleziono liczącą 500 tys. tomów zrabowanych głównie z Węgier i Francji bibliotekę Arbeits Frontu ukrytą w czasie odwrotu armii niemieckiej w tamtejszym młynie ${ }^{27}$. Znaleziskiem zajął się Wojewódzki Wydział Kultury i Sztuki.

Warto wspomnieć o inicjatywach przesiedlonych, którzy własnymi staraniami próbowali zaspokajać głód polskich podręczników i książek. 22 VII 1945 r. we Wrocławiu otwarta została prywatna Biblioteka Naukowa „Książka na Śląsk" Władysława S. Kazanowicza urodzonego w Mohylewie na Białorusi, przed II wojną światową związanego m.in. z Krakowem ${ }^{28}$. W.S. Kazanowicz oferował czytelnikom głównie podręczniki akademickie. Z kolei pierwsza prywatna wypożyczalnia książek „Oświata” uruchomiona została także we

27 „Pionier. Dziennik Dolno-Śląski”, 27 IX 1945, nr 28, s. 4.

28 B. Koredczuk, Idea „Biblioteki otwartej” Władysława Sergiusza Kazanowicza (19151969). Poczatki biblioteki jako trzeciego miejsca, „Roczniki Biblioteczne” 2015, R. 59, s. 47-50. 
Wrocławiu, blisko placu Uniwersyteckiego, już 16 IX 1945 r. Właściciel Zdzisław Błażewski pochodzący ze Stryja - dysponował księgozbiorem liczącym 1000 egzemplarzy. Opłata miesięczna za korzystanie z wypożyczalni

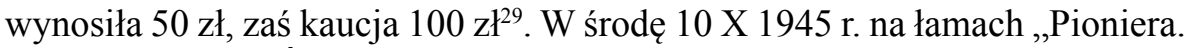
Dziennika Dolno-Śląskiego" w rubryce ogłoszeń drobnych ukazała się krótka notka, iż w Legnicy, wówczas Lignicy, przy ul. Grodzkiej działa „Biblioteka dzieł wyborowych, czynna od 13-stej do 19-stej" ${ }^{30}$. Warto odnotować fakt, iż oprócz starań o stworzenie warsztatu pracy dydaktycznej i naukowej podejmowanych przez środowisko uczonych związanych z organizowanym we Wrocławiu Uniwersytetem i Politechniką, udostępnianiem książki polskiej zajmowali się również kolekcjonerzy prywatni. Zawartą w Manifeście PKWN deklarację - Inicjatywa prywatna, wzmagajaca tętno życia gospodarczego, również znajdzie poparcie państwa - niestety już od czerwca 1947 r. ograniczała tzw. bitwa o handel skutkująca likwidacją w Polsce sektora prywatnego. Obostrzenia i restrykcje dotknęły również biblioteki i wypożyczalnie prywatne, których z różnych względów nie było na Dolnym Śląsku wiele.

\section{Język polski w Okręgu II Dolny Śląsk}

Pojawienie się informacji o zbiórkach książek dla organizowanych bibliotek poprzedziły dokumenty ogłaszające nakaz likwidacji niemieckich napisów w przestrzeni dolnośląskich miejscowości. Tego rodzaju druki opracowywały władze regionu, prezydenci miast oraz urzędnicy miejscy np. kierownicy Referatów Aprowizacji i Handlu. Pełnomocnik Rządu RP na miasto Wrocław $\mathrm{w}$ jednym z pierwszych obwieszczeń adresowanych do przesiedlonych wzywał „wszystkich właścicieli, administratorów lub posiadaczy nieruchomości, aby w ciągu tygodnia od daty [24 VIII 1945 r. - AFB] niniejszego usunęli napisy niemieckie, znajdujące się na nieruchomościach" ${ }^{31}$. Osobom uchylającym się od wykonania polecenia groziła odpowiedzialność karna oraz obciążenie kosztami usunięcia napisów. Tego rodzaju polecenia edytowano jeszcze w $1946 \mathrm{r}$. m.in. w Legnicy zakazując upubliczniania informacji, takich jak szyldy czy napisy na towarach w języku niemieckim.

Ważną datą z punktu widzenia obecności języka polskiego na Dolnym Śląsku był poniedziałek 27 VIII 1945 r., kiedy ukazał się pierwszy numer dziennika „Pionier”. Gazeta drukowana była w legnickiej Drukarni i Wydawnictwie delegatury „Czytelnika”. Co ciekawe, na łamach tego numeru zamieszczono wówczas krótką informację pt. Polska biblioteka m. Gdańska. Czytelników

29 „Pionier. Dziennik Dolno-Śląski”, 16 IX 1945, nr 19, s. 4.

30 „Pionier. Dziennik Dolno-Śląski”, 10 X 1945, nr 39, s. 4.

31 Obwieszczenie Pełnomocnika Rządu RP na Obwód 39 miasto Wrocław z dnia 24 VIII 1945 r. ze zbiorów Biblioteki Uniwersyteckiej we Wrocławiu. 
powiadamiano o pracach nad uruchomieniem książnicy, która przed rokiem 1939 posiadała 300 tys. tomów, w tym ,bogato reprezentowany dział «poloników», stwierdzających niezbicie odwieczną polskość Gdańska i jego przynależność do Macierzy" ${ }^{32}$. W notce zawarto też komunikat o Bibliotece Katedralnej w Oliwie oraz o polskich książkach odnalezionych w Malborku i Pelplinie. We wrześniu 1945 r. także na łamach tego pisma Tadeusz Tułasiewicz (1902-1985), dziennikarz i działacz społeczny zasłużony dla regionu, apelował do uczestników odbywającego się w Krakowie Zjazdu Literatów Polskich o opiekę nad uruchomieniem bibliotek na Dolnym Śląsku. W świetle tekstu T. Tułasiewicza przesiedleni ,poza gazetą nie widzą żadnego innego drukowanego słowa polskiego"33. Pierwsza biblioteka publiczna we Wrocławiu, nie licząc inicjatyw prywatnych, rozpoczęła swoje funkcjonowanie 30 IX $1945 \mathrm{r}$. w gmachu Zarządu Miejskiego. Jednak z uwagi na bardzo skromny księgozbiór liczący zaledwie 800 tomów mogli z niej korzystać wyłącznie pracownicy urzędów miejskich legitymujący się odpowiednimi dokumentami ${ }^{34}$.

Sprawa obecności języka polskiego w Okręgu II Dolny Śląsk, jak i polskich książek w uruchamianych szkołach, stanowiła przedmiot troski władz regionu, jak i organizacji obywatelskich, które z czasem rozpoczęły tu swoją działalność. Aktywność tych podmiotów różniła się początkowo w zakresie intencji, jak i możliwości realizacji wyznaczonych planów oraz zamierzeń. Cele i zadania spełniane przez administrację wojewódzką obejmowały m.in. propagandowe ukazywanie historycznych związków Ziem Odzyskanych z Rzecząpospolitą, tłumaczenie przesiedlonym, iż obecność ludności polskiej na tych terenach stanowi wyraz dziejowej sprawiedliwości, jak również próbę scalenia tych okręgów z innymi regionami Polski, z polską historią i kulturą. Jednocześnie w publikacjach podawanych do wiadomości publicznej przemilczano i nie wspominano o miejscach, które nakazano opuścić, choć tam tworzyła się polska tożsamość. Stowarzyszenia a także związki służące dobru publicznemu próbowały natomiast wspierać przybyłą ludność i udzielać pomocy m.in. $\mathrm{w}$ zakresie zaspokajania podstawowych potrzeb oraz $\mathrm{w}$ procesie budowania społecznych relacji w regionie, gdzie doszło do całkowitej wymiany ludności. Formowane oddolnie organizacje społeczne swoją działalność w Okręgu II Dolny Śląsk rozpoczynały w chwili, gdy na miejscu pojawiali się ich członkowie powołujący nowe regionalne oddziały danego związku czy towarzystwa. Pierwszą tego rodzaju organizacją był Polski Czerwony Krzyż, który wraz z Państwowym Urzędem Repatriacyjnym udzielał migrującym oraz przybyłym do Okręgu II podstawowej opieki medycznej, wydawał posiłki, organizował

32 „Pionier. Dziennik Dolno-Śląski”, 27 VIII 1945, nr 1, s. 4.

33 „Pionier. Dziennik Dolno-Śląski”, 29 IX 1945, nr 30, s. 3.

34 „Pionier. Dziennik Dolno-Śląski”, 29 IX 1945, nr 31, s. 4. 
punkty sanitarne, szpitale, sierocińce oraz sanatoria dla tych, którzy przetrwali piekło hitlerowskich obozów koncentracyjnych. W przypadku innych organizacji rozpoczęcie działalności wymagało jednak czasu a przede wszystkim uporządkowania bardzo trudnej sytuacji na Ziemiach Zachodnich i Północnych zwanych nawet Dzikim Zachodem.

Warto w tym miejscu odnieść się do problemu skali strat dóbr kultury i dziedzictwa narodowego zgromadzonego w przedwojennych bibliotekach polskich a następnie zniszczonego przez okupantów. Na łamach „Pioniera. Dziennika Dolno-Śląskiego" informowano m.in. o tymczasowych obliczeniach czynionych wówczas dla celów reparacyjnych przez Biuro Odszkodowań Wojennych Prezydium Rady Ministrów. Szef Biura - Emil Sommerstein we wrześniu 1945 roku szacował, iż „straty [...] w bibliotekach, [...] w rękopisach są olbrzymie, choć nie dają się ująć w cyfry" ${ }^{35}$. Próby precyzyjnego, udokumentowanego określenia rachunku strat wojennych polskich księgozbiorów czyniono bezpośrednio po wojnie w okresie 1945-1947, jak i w latach późniejszych, szczególnie w momentach, kiedy łagodniała polityka represyjna władz np. w latach 70. XX w. oraz w okresie 1992-2000, gdy w Ministerstwie Kultury powołane zostało Biuro Pełnomocnika Rządu do Spraw Polskiego Dziedzictwa Kulturowego za Granicą. Dane opisane m.in. w opracowaniu Straty bibliotek w czasie II wojny światowej w granicach Polski z 1945 roku. Wstęny raport o stanie wiedzy. Cz. 1-2 (Warszawa 1994) pod red. Barbary Bieńkowskiej i Andrzeja Mężyńskiego a także w innych publikacjach pod red. B. Bieńkowskiej Biblioteki na Wschodnich Ziemiach II Rzeczypospolitej (Poznań 1998), Informator o stratach bibliotek $i$ księgozbiorów domowych na terytoriach polskich okupowanych w latach 1939-1945 (bez ziem wschodnich) (Poznań 2000), ujawniają przerażającą skalę nieodwracalnego zniszczenia zasobów dziedzictwa polskiej kultury. Zrekompensowanie tych strat, obejmujących również zniszczenia budynków oraz ich wyposażenia, nie było możliwe z różnych przyczyn ani bezpośrednio po wojnie, ani później. Odrębny problem stanowiły straty, których doznało środowisko polskiej książki i biblioteki ${ }^{36}$. Jedno z pierwszych opracowań na ten temat, autorstwa Marii Rutowskiej, oparte m.in. na danych Centralnej Kartoteki Strat Inteligencji Polskiej zawiera 168 nazwisk bibliotekarzy polskich, którzy w okresie II wojny światowej zginęli w wyniku wojny, zostali zamordowani w hitlerowskich obozach koncentracyjnych Dachau, Auschwitz, Buchenwald, Sachsenhausen-Oranienburg, Mauthausen-Gusen, Neuengamme, Hohenbruch, Bergen-Belsen, Majdanek, miejscach kaźni polskiej inteligencji w Katyniu, w gułagach na nieludzkiej ziemi lub miejscach zsyłek

35 „Pionier. Dziennik Dolno-Śląski”, 15 IX 1945, nr 1, s. 3.

36 Stan strat środowiska polskiej książki i biblioteki przedstawiano po II wojnie światowej m.in. na łamach „Bibliotekarza” i „Przeglądu Bibliotecznego” (1947 R. 14 s. 183-185). 
w głębi ZSRR ${ }^{37}$. Fakt ten miał nieodwracalne, negatywne skutki dla rozwoju cywilizacyjnego Polaków, w szczególności dzieci i młodzieży. Odczuwany był szczególnie silnie w okresach narastającego stalinizmu.

Próbę przedstawienia na bieżąco szacunku strat wojennych doznanych przez polskie biblioteki podjął również zasłużony organizator bibliotekarstwa polskiego Józef Grycz, m.in. w artykule Problemy biblioteczne obecnej doby ${ }^{38}$. J. Grycz określił w tym tekście straty zarówno możliwe do określenia w pieniądzach, jak i niewymierne i niemożliwe do uzupełnienia. Szacunki te stanowiły podstawę działań naprawczych podejmowanych przez środowisko bibliotekarzy polskich i jednocześnie wskazywały na konieczność organizowania powojennego bibliotekarstwa właściwie od podstaw. Za najważniejsze osiągnięcia pierwszych lat po wyzwoleniu J. Grycz uznawał w pierwszej kolejności Dekret $z$ dnia 17 kwietnia 1946 r. o bibliotekach i opiece nad zbiorami bibliotecznymi (Dz. U. 1946 nr 26 poz. 163) a także skupiające sprawy książki podmioty powoływane przez Ministerstwo Oświaty i działające w jego strukturze. Były to m.in.: Wydział Bibliotek, który obejmował referaty: ogólnoorganizacyjny, bibliotek szkolnych, bibliotek powszechnych, bibliotek naukowych. W jednostce tej od czerwca 1945 r. działał też Oddział Dawnej Książki a także referaty odpowiedzialne za rejestrację strat i szkód wojennych, rewindykację, odszkodowania oraz zabezpieczenie księgozbiorów opuszczonych i porzuconych ${ }^{39}$. Obawy i wątpliwości Grycza budził m.in. urzędowo-administracyjny, a nie organizacyjno-fachowy charakter działań Wydziału Bibliotek, a także problemy związane ze zwiększeniem produkcji wydawniczej oraz możliwe do uzyskania odszkodowania i reparacje od Niemców obejmujące starania o konkretne dobra materialne np. papier i maszyny drukarskie. W przytoczonym tekście J. Grycz pozytywnie oceniał również powołanie w 1946 r. Naczelnej Dyrekcji Bibliotek oraz Państwowego Instytutu Książki i Rady Książki.

Wśród działań podejmowanych w latach 1945-1948 przez Ministerstwo Oświaty, które starało się poprawić rozpaczliwy brak książek polskich, warto wspomnieć o pierwszej powojennej rejestracji bibliotek oświatowych i szkolnych w Polsce w jej nowych granicach. Rejestrację przy pomocy rozesłanych do różnych typów bibliotek kart rejestracyjnych przeprowadzały w lutym 1946 r. kuratoria okręgów szkolnych oraz inspektoraty szkolne na prośbę Naczelnej Dyrekcji Bibliotek. Celem tej inwentaryzacji była próba określenia stanu bibliotek polskich na dzień 1 I 1946 r., w tym bibliotek działających na Ziemiach Odzyskanych. Pomimo licznych przeszkód utrudniających przeprowadzenie tego zadania, ewidencja wykazała, iż na Ziemiach Odzyskanych

37 Za: M. Rutowska, Lista strat osobowych bibliotekarstwa polskiego w czasie II wojny światowej, „Przegląd Biblioteczny” 1981, z. 2, s. 177-192.

38 J. Grycz, Problemy biblioteczne obecnej doby, „Przegląd Biblioteczny” 1946, R. 14, s. 4-24.

39 Tamże, s. 22-24. 
dostęp do polskich książek i bibliotek był najtrudniejszy. W świetle opublikowanego w styczniu 1946 r. na łamach „Bibliotekarza” artykułu Wyniki rejestracji bibliotek Czesława Kozioła, pełniącego wówczas funkcję wizytatora w Wydziale Bibliotek Powszechnych i Szkolnych oraz naczelnika Wydziału Bibliotek Naukowych w Naczelnej Dyrekcji Bibliotek, jeden tom przypadał na 36,6 mieszkańców Ziem Odzyskanych ${ }^{40}$. Dla porównania na terenach tzw. dawnych jeden tom przypadał średnio na 9,5 mieszkańców. Zgodnie z zebranymi danymi Polacy zamieszkujący wsie na Ziemiach Odzyskanych nie mieli praktycznie dostępu do polskich książek - jeden tom przypadał na ponad 265 mieszkańców. Dane Biura Badań i Statystyki działającego przy Ministerstwie Oświaty wskazywały, iż na całym obszarze Ziem Odzyskanych działało 2917 szkół powszechnych, w których istniały zaledwie 392 biblioteki szkolne. W szkołach tych uczyło się ponad 318 tys. Dzieci. Aż 84\% szkół na Ziemiach Odzyskanych nie posiadało biblioteki, jeden tom przypadał statystycznie na ponad 18 uczniów ${ }^{41}$.

\section{Zbiórki książek w Okręgu II Dolny Śląsk}

Zbiórki książek w Okręgu II Dolny Śląsk organizowano już w roku 1945 a także później w latach 1946-1947. Zachowane źródła ulotne pochodzące ze zbiorów Gabinetu Śląsko-Łużyckiego Biblioteki Uniwersyteckiej we Wrocławiu oraz Biblioteki Zakładu Naukowego im. Ossolińskich wskazują, iż zbiórki książek lub datków na ich zakup prowadzono we przede wszystkim we Wrocławiu i Legnicy, a także w Jeleniej Górze, Dzierżoniowie oraz gminie Sadlno należącej obecnie do województwa wielkopolskiego.

Początkowo miejscem największej liczby zbiórek książek była Legnica, do której z powodu ogromnych zniszczeń Wrocławia przeniosły się władze województwa. Jednak tuż po ogłoszeniu rządowej decyzji o „przywróceniu Warszawie splendoru stolicy Polski", działacz partyjny Stanisław Januszewski donosił, iż rządzący w Okręgu II Dolny Śląsk, zdecydowali się powrócić do Wrocławia. ${ }^{42}$ Zgodnie z założeniami stolica Dolnego Śląska miała mieć charakter miasta robotniczego, podobnie zresztą jak cały region. Władze informowały też, iż stopniowo wraz z postępującą odbudową, zaspokajane będą wszelkie inne potrzeby mieszkańców i osadników. W tym ambicje edukacyjne i naukowe młodzieży, które realizowane miały być w organizowanych uczelniach Wrocławia uznanego przez powojenny rząd za miasto $\mathrm{z}$ długoletnimi tradycjami akademickimi.

40 Cz. Kozioł, Wyniki rejestracji bibliotek, „Bibliotekarz”, XI-XII 1946, R. 13, nr 11-12, s. $223-226$

41 Tamże, s. 226.

42 „Pionier. Dziennik Dolno-Śląski”, 15 IX 1945, nr 18, s. 1. 
Już w 1945 r. we wrześniu uruchomiono pierwszą w Legnicy wypożyczalnię polskich książek beletrystycznych. Jak wspominał Bogumił Miłaszewski - historyk i długoletni pracownik Wydziału Kultury Urzędu Miejskiego we Wrocławiu - w maszynopisie przekazanym do Biblioteki Zakładu Narodowego im. Ossolińskich, początkowo księgozbiór liczył 200 tomów książek polskich pochodzących z darów pracowników Urzędu Wojewódzkiego ${ }^{43}$. Otwarcie biblioteki poprzedziła najprawdopodobniej pierwsza zbiórka książek zorganizowana w sierpniu przez umiejscowiony w Legnicy Wojewódzki Wydział Kultury i Sztuki.

Il. 2. „Pionier. Dziennik Dolno-Śląski”, 30 IX1945, nr 31, s. 4

\section{ZYVIE RULTURALNE}

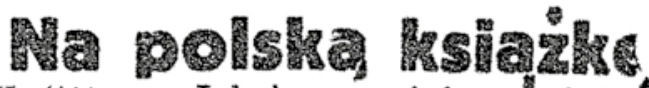

WROCEAW (tt). - Jak in- powinien zhaleźć ualszych, liczformuje Wydzial Kultury i Sztu nych naśladowców.

ki Zarządu Miejskiego we Wroclawiu apel $\mathrm{w}$ sprawie książki znalazl już pewien oddźwięk w wydzialu kultury i sztuki Zaspoleczeństwie. Jako pierwszych rzadu Miejskiego we Wroclawiu ofiarodawców należy zanoto- wpłynęły dalsze datki a mianować ob. ob. Gryszkiewicza Ta- wicie: Kaniówna Ewa i Galindeusza i Jaworskiego Kazimierza, którzy złóyli na rzecz wydziału zl 4000 i Hołuszkę Aleksandra, który złożył $2.000 \mathrm{zl}$. Ten czyn obywatelski zashuguska Alfreda złożyły po $20 \mathrm{zl}$ i wzywaja do składki Wichlinska Izabellę oraz Gruszecką Irenę, rozpoczynając tym samym „łańje na specjalne wyróżnienie il

W dniach 26 VIII - 2 IX 1945 r. na terenie całego Dolnego Śląska miała miejsce zbiórka książek pod hasłem „Tydzień Książki”. „Pionier. Dziennik Dolno-Śląski” donosił: „brak lektury (...) szczególnie dotkliwy jest jednak tu, u nas. Gorący przeto apel do ludzi, którzy książkę otoczą troskliwą opieką i udostępnią korzystanie z niej szerokim masom" ${ }^{44}$. Akcję propagowały plakaty, dzięki którym w wydarzeniu brali udział m.in. członkowie organizacji społeczno-politycznych oraz harcerze, którzy zebrali rekordową liczbę 1000 egzemplarzy książek napisanych w języku niemieckim ${ }^{45}$. Według doniesień B. Miłaszewskiego „z 15. powiatów zebrano wówczas ponad ćwierć miliona

43 B. Miłaszewski, dz. cyt.

44 „Pionier. Dziennik Dolno-Śląski”, 27 VIII 1945, nr 18, s. 3.

45 „Pionier. Dziennik Dolno-Śląski”, 29 VIII 1945, nr 3, s. 4; 6 września, nr 10, s. 4. 
książek niemieckich oraz wydawnictw muzycznych, z których około 355 było cennymi dziełami z różnych dziedzin wiedzy. (...) Wpadały w naszą sieć sensacyjne dokumenty hitlerowskie, fotografie, mapy sztabowe, stare foliały akt sądowych i miejskich, z ważnymi dla nas danymi statystycznymi z początków XIX wieku" ${ }^{\prime 4}$.

Wydział Kultury i Sztuki Zarządu Miejskiego po przeprowadzce do Wrocławia organizował m.in. we wrześniu $1945 \mathrm{r}$. tzw. łańcuchy ofiar - wezwania do datków na zakup książek dla biblioteki miejskiej. Wezwania te ogłaszano imiennie w prasie np. „Kaniówna Ewa i Galińska Alfreda złożyły po 20 zł i wzywają do składki Wichlińską Izabellę oraz Gruszecką Irenę" ${ }^{\text {"7 }}$.

W łańcuchu darczyńców nie zabrakło partii politycznych m.in. członkowie Sekcji Kulturalnej PPS wpłacili rekordową kwotę 1000 zł. Podobny łańcuch ofiar, jak i wysokość wpłat darczyńców anonimowych (20 zł), przedstawiono w numerze 38. „Pioniera. Dziennika Dolno-Śląskiego” z dnia 9 X 1945 r.

W październiku 1945 r., już po rozpoczęciu w Okręgu II Dolny Śląsk roku szkolnego, ogłoszono akcję społeczną „Dar książki dla Wrocławia i Śląska”. Organizatorami tej dużej ogólnopolskiej zbiórki książek niezbędnych do funkcjonowania dolnośląskich bibliotek były Kuratorium Okręgu Szkolnego Krakowskiego, Kuratorium Okręgu Szkolnego Kieleckiego, Kuratorium Okręgu Szkolnego Rzeszowskiego, Okręgowa Komisja Związków Zawodowych, Krakowskie Towarzystwo Prawnicze, Związek Dziennikarzy, Związek Księgarzy, Związek Literatów, Związek Nauczycieli Polskich, Związek Artystów Scen Polskich, Związek Harcerstwa Polskiego, Bratnia Pomoc Uniwersytetu Jagiellońskiego, Bratnia Pomoc Akademii Górniczej oraz Biblioteka Jagiellońska. Organizatorzy przy pomocy patetycznych haseł, odwołując się do czynów zbrojnych polskich żołnierzy, przekonywali czytelników i potencjalnych darczyńców, iż:

[...] Czyn zbrojny woła o czyny serca i rozumu! Ojczysty język jest jedyną najtrwalszą więzią Narodu! Tam nad Odrą a Nysą mimo wszystko przetrwał on 600 lat! Trzeba go wzmocnić, rozbudować, usunąć części z obcych nalotów, stworzyć dlań wieczną podstawę!"

Zbiórki książek na rzecz uruchamianych w Okręgu II Dolny Śląsk bibliotek prowadzono intensywnie również w $1946 \mathrm{r}$. Zbierano wówczas także fundusze na zakup książek i map. Już na początku roku, w sobotę 23 lutego Komisja Porozumiewawcza Organizacji Młodzieżowych na Dolnym Śląsku ,pod protektoratem Pełnomocnika Rządu RP na Okręg Administracyjny Dolnego Śląska ob. Mgr. Piaskowskiego Stanisława" urządziła wielką zabawę taneczną. Pierwszorzędna orkiestra jazzowa, obficie zaopatrzony bufet, atrakcje i niespodzianki

46 B. Miłaszewski, dz. cyt.

47 „Pionier. Dziennik Dolno-Śląski”, 30 IX1945, nr 31, s. 4.

48 Afisz z października 1945 r. „Dar książki dla Wrocławia i Śląska”, dz. cyt. 
„W sali dobrze ogrzanej” miały sprzyjać hojności darczyńców ${ }^{49}$. Organizator informował, iż dochód z zabawy przeznaczony zostanie na zakup książek oraz sprzętu sportowego.

W dniach 1-3 V 1946 r. odbyło się na Dolnym Śląsku pierwsze Święto Oświaty, którego naczelnym tematem [miała być - AFB] książka, ze szczególnym uwzględnieniem zagadnień bibliotek publicznych, w związku z wejściem w życie dekretu o bibliotekach i opiece nad zbiorami bibliotecznymi”. W czasie wydarzenia gromadzono fundusze na zakup książek do organizowanych we Wrocławiu bibliotek. We wrześniu 1946 r. bardzo aktywne na Dolnym Śląsku Towarzystwo Przyjaciół Żołnierza we wrocławskiej Drukarni „Wiedzy” publikowało hasła „Biblioteka Towarzystwa Przyjaciół Żołnierza jest bez książek! Złóż dla Żołnierza książkę!"50. W tym samym czasie również Drukarnia Państwowa nr 1 we Wrocławiu edytowała hasła zachęcające do oddawania książek „Daj książkę do biblioteki publicznej”, „Książka skarbnicą kultury!”. Niestety druki nie informowały o autorach tej akcji. Podobne akcje odbywały się w Legnicy, gdzie 6 VII 1946 r. Powiatowa Komenda MO urządziła zabawę taneczną, na którą zaproszono „obywateli Legnicy”"51. Koszt biletu wynosił 50 zł a całkowity dochód przeznaczono na budowę świetlicy oraz zakup książek. 20 VII 1946 r. Związek Pracowników Dróg Kołowych Rzeczypospolitej Polskiej Oddział w Legnicy zorganizował całonocną zabawę taneczną w lokalu Zacisze. Całkowity dochód z imprezy przeznaczono „na założenie biblioteki”, ${ }^{52}$. Zachowane źródła wskazują, iż zbiórki książek lub funduszy na ich zakup zajmowały się również uruchamiane na Dolnym Śląsku szkoły. W zasobach Gabinetu Śląsko-Łużyckiego Biblioteki Uniwersyteckiej zachował się unikatowy afisz edytowany przez Drukarnię „Czytelnik” w Legnicy. Autorem druku było Państwowe Liceum Pedagogiczne w Legnicy, które zapraszało mieszkańców miasta na „Wieczór śpiewu, muzyki i tańca"53. Wykonawcami przedstawienia byli uczniowie liceum oraz młodzież ze Szkoły Ćwiczeń funkcjonującej w tym samym budynku. Ceny biletów wynosiły 70, 80, 100 i 150 zł. Dochód przeznaczono na zakup książek oraz pomoce naukowe. Z kolei 17 VIII 1947 r. z okazji uroczystych dożynek w gminie Sadlno urządzono m.in. uroczysty obiad, loterię fantową oraz zabawę taneczną. Dochód z wydarzenia przeznaczono na „zakup

49 Afisz Komisji Porozumiewawczej Organizacji Młodzieżowych na Dolnym Śląsku z 23 II 1946 r., ze zbiorów Biblioteki Uniwersyteckiej we Wrocławiu.

50 Hasło: Biblioteka Towarzystwa Przyjaciót Żotnierza jest bez książek! Złóż dla Żotnierza ksiązkę!, wrzesień 1946 r., ze zbiorów Biblioteki Uniwersyteckiej we Wrocławiu.

51 Afisz Powiatowej komendy MO w Legnicy, lipiec 1946 r., ze zbiorów Biblioteki Uniwersyteckiej we Wrocławiu.

52 Afisz Związku Pracowników Dróg Kołowych Rzeczypospolitej Polskiej Oddział w Legnicy, 20 VII 1946 r., ze zbiorów Biblioteki Uniwersyteckiej we Wrocławiu.

53 Afisz Państwowego Liceum Pedagogicznego w Legnicy z 11 V 1947 r., ze zbiorów Biblioteki Uniwersyteckiej we Wrocławiu. 
książek szkolnych dla najuboższych dzieci z gminy Sadlno"54. Co ciekawe przedstawiany druk edytowany był przez Drukarnię Państwową w Ząbkowicach Śląskich przy użyciu niemieckich czcionek.

Sprawą urządzania na Dolnym Śląski bibliotek zajmowały się również organizowane od podstaw na Dolnym Śląsku podmioty np. Organizacja Młodzieżowa Towarzystwa Uniwersytetu Robotniczego (OM TUR), której pierwsze założycielskie zebranie odbyło się we Wrocławiu dnia 10 IX 1945 r. Towarzystwo oprócz zakładania świetlic „wysuwało na pierwszy plan tworzenie bibliotek" dla uczącej się młodzieży ${ }^{55}$.

\section{Zakończenie}

Źródła ulotne zachowane w zasobach Gabinetu Śląsko-Łużyckiego Biblioteki Uniwersyteckiej we Wrocławiu, maszynopisy pochodzące z Działu Dokumentów Życia Społecznego Biblioteki Zakładu Narodowego im. Ossolińskich oraz archiwalne numery „Pioniera. Dziennika Dolno-Śląskiego” wskazują, iż sprawa polskiej książki było obecna w życiu przesiedlonych oraz dokumentują aktywność podejmowaną przez osiedlających się Polaków w celu zakupu książek do organizowanych od podstaw bibliotek. Aktywność ta obejmowała działania organizowane przez instytucje szczebla centralnego, regionalnego oraz lokalnego. Zachowane źródła ujawniają, iż o dostęp do ojczystej literatury dbały instytucje edukacji, oświaty i nauki, licznie działające w okresie 1945-1948 stowarzyszenia i organizacje społeczne, związki zawodowe oraz sami przesiedleni. Oprócz ogromnego trudu organizacyjnego, wydźwignięcia z ruin stolicy Dolnego Śląska, ponoszenia ciągłych kosztów odbudowy Polski, przesiedleni mieszkańcy nie szczędzili środków finansowych i darów, aby wspierać organizowane od podstaw biblioteki.

\section{Bibliografia}

Dunin-Wąsowicz K., Warszawa w latach 1939-1945, pod red. B. Bieńkowskiej, Warszawa 1984.

Firlej-Buzon A., Działalność prof. Antoniego Knota w organizacji bibliotekarstwa naukowego na Dolnym Śląsku w latach 1945-1956, „Zielonogórskie Studia Bibliotekoznawcze" 2017, z. 9, s. 155-166.

Gawryszewski A., Ludność Polski w XX wieku, Warszawa 2005.

Grycz J., Problemy biblioteczne obecnej doby, „Przegląd Biblioteczny” 1946, R. 14, s. 4-24.

54 Afisz Komitetu Organizacyjnego Dożynek, sierpień 1947 r., ze zbiorów Biblioteki Uniwersyteckiej we Wrocławiu.

55 „Pionier. Dziennik Dolno-Śląski”, 14 IX1945, nr 17, s. 4. 
Informator o stratach bibliotek i księgozbiorów domowych na terytoriach polskich okupowanych w latach 1939-1945 (bez ziem wschodnich), Poznań 2000.

Jarosz D., Dni Oświaty, Książi i Prasy w systemie propagandy kulturalnej władz Polski Ludowej 1946-1956, „Polska 1944/45-1989. Studia i materiały” 2011, t. 10, s. 46.

Koredczuk B., Idea „Biblioteki otwartej” Wtadysława Sergiusza Kazanowicza (19151969). Poczatki biblioteki jako trzeciego miejsca, „Roczniki Biblioteczne” 2015, R. 59, s. 47-50.

Kozioł Cz., Wyniki rejestracji bibliotek, „Bibliotekarz”, XI-XII 1946, R. 13, nr 11-12, s. 223-226.

Lanckorońska K., Wspomnienia wojenne, Kraków 2001.

Rutowska M., Lista strat osobowych bibliotekarstwa polskiego w czasie II wojny światowej, ,Przegląd Biblioteczny” 1981 (2), s. 177-192.

Straty bibliotek polskich w czasie II [drugiej] wojny światowej, pod red. B. Bieńkowskiej, Warszawa 1994.

Szocki J., Antoni Knot (1904-1982), „Nauka Polska” 1982, nr 1-2, s. 269-271.

Wałęga J., Deportacje i przesiedlenia, Rzym 1945.

Wieliczko M., Raport o „,strojbatach”, „Annales Univesitatis Mariae Curie-Skłodowska Lublin Polonia" 2008, nr 58, s. 119.

„Pionier. Dziennik Dolno-Śląski” z lat 1945-1946. 